\title{
A Bacterial Type III Secretion Assay for Delivery of Fungal Effector Proteins into Wheat
}

\author{
Narayana M. Upadhyaya, ${ }^{1}$ Rohit Mago, ${ }^{1}$ Brian J. Staskawicz, ${ }^{2}$ Michael A. Ayliffe,,${ }^{1}$ Jeffrey G. Ellis, ${ }^{1}$ and \\ Peter N. Dodds ${ }^{1}$ \\ ${ }^{1}$ CSIRO Plant Industry Australia, Box 1600, Clunies Ross Street, Canberra, ACT, 2601, Australia; ${ }^{2}$ University of California, \\ Berkeley, U.S.A.
}

Submitted 2 July 2013. Accepted14 October 2013.

\begin{abstract}
Large numbers of candidate effectors from fungal pathogens are being identified through whole-genome sequencing and in planta expression studies. Although Agrobacteriummediated transient expression has enabled high-throughput functional analysis of effectors in dicot plants, this assay is not effective in cereal leaves. Here, we show that a nonpathogenic Pseudomonas fluorescens engineered to express the type III secretion system (T3SS) of $P$. syringae and the wheat pathogen Xanthomonas translucens can deliver fusion proteins containing T3SS signals from $P$. syringae (AvrRpm1) and $X$. campestris (AvrBs2) avirulence (Avr) proteins, respectively, into wheat leaf cells. A calmodulin-dependent adenylate cyclase reporter protein was delivered effectively into wheat and barley by both bacteria. Absence of any disease symptoms with $P$. fluorescens makes it more suitable than $X$. translucens for detecting a hypersensitive response (HR) induced by an effector protein with avirulence activity. We further modified the delivery system by removal of the myristoylation site from the AvrRpm1 fusion to prevent its localization to the plasma membrane which could inhibit recognition of an Avr protein. Delivery of the flax rust AvrM protein by the modified delivery system into transgenic tobacco leaves expressing the corresponding $M$ resistance protein induced a strong HR, indicating that the system is capable of delivering a functional rust Avr protein. In a preliminary screen of effectors from the stem rust fungus Puccinia graminis f. sp. tritici, we identified one effector that induced a host genotype-specific HR in wheat. Thus, the modified AvrRpm1:effector-Pseudomonas fluorescens system is an effective tool for large-scale screening of pathogen effectors for recognition in wheat.
\end{abstract}

Establishment of disease by biotrophic plant pathogens requires the pathogen to overcome plant basal defenses, and current theory proposes that this is due to the action of secreted effector proteins (Rafiqi et al. 2012). Effectors, however, can be recognized by plant resistance $(\mathrm{R})$ proteins in a gene-forgene manner, as first defined in the flax rust disease system (Flor 1971). The recognition of pathogen effectors or avirulence (Avr) proteins commonly leads to rapid activation of a

Corresponding author: N. M. Upadhyaya; Telephone +61 262465491 ; E-mail: Narayana.upadhyaya@csiro.au

* The $\boldsymbol{e}$-Xtra logo stands for "electronic extra" and indicates that three supplementary tables and two supplementary figures are published online.

(C) 2014 The American Phytopathological Society hypersensitive response (HR), a cell death response by which plants are thought to arrest pathogen spread from the infection site (Chisholm et al. 2006).

Wheat stem rust, Puccinia graminis f. sp. tritici, is one of the most destructive pathogens of wheat, barley, and other small grain cereals (Leonard and Szabo 2005; Park 2007). Although there are a number of plant $R$ genes deployed in modern wheat cultivars, resistance breakdown occurs frequently through mutation of $A v r$ genes (Stokstad 2007). Identifying P. graminis $\mathrm{f}$. sp. tritici Avr genes will help understand how virulence evolves and will facilitate isolation of new $R$ genes. Much of our current understanding of the role of rust pathogen Avr or effector proteins comes from the flax (Linum usitatissimum) and flax rust (Melampsora lini) disease system (Lawrence et al. 2007), where it has been shown that these proteins are delivered into host cells and can be recognized by direct interaction with corresponding host R proteins (Barrett et al. 2009; Catanzariti et al. 2006, 2010; Dodds et al. 2004, 2006). During infection, rust hyphae grow within the leaf apoplast and then form a close association with host mesophyll cells by the development of haustoria, which are thought to be the primary site of nutrient acquisition from the plant (Voegele and Mendgen 2003) and secrete effectors that are targeted to the cytoplasm of host cells (Catanzariti et al. 2006; Kemen et al. 2005; Rafiqi et al. 2010). Sequencing of the $P$. graminis $\mathrm{f}$. $\mathrm{sp}$. tritici genome (Duplessis et al. 2011) has led to the identification of approximately 200 candidate effector genes which encode small proteins with predicted secretion peptide signals expressed in haustoria (unpublished data). Testing such large numbers of candidates requires high-throughput assays that can be applied to wheat.

Agrobacterium-mediated transient expression has been a powerful tool for flax rust effector analysis in dicot plant hosts (Catanzariti et al. 2006; Dodds et al. 2004); however, these assays have not been successful in wheat. A transient assay for Avr activity has been developed for cereals via biolistic transformation (Leister et al. 1996) and used in rice (Jia et al. 2000) and barley (Bai et al. 2012). In this assay, Avr activity is detected as a loss of reporter protein $(\beta$-glucuronidase or green fluorescent protein) expression which is eclipsed by the induction of cell death upon Avr recognition. This relatively laborintensive method, however, is not easily adapted to high throughput screening and generally limited to epidermal cell expression. Avr activities have also been assayed to a limited extent in rice by protoplast transformation (Kanzaki et al. 2012; Okuyama et al. 2011; Yoshida et al. 2009). An alternative approach for effector or Avr screening is to deliver proteins into plant cells by utilizing the type III secretion system (T3SS) of a bacterial plant pathogen. For instance, Sohn and 
associates (2007) showed that several oomycete effector proteins could be delivered to Arabidopsis by Pseudomonas syringae pv. tomato (DC3000) when fused to the N-terminal secretion-translocation signals of the well-characterized bacterial effectors AvrRpm1 or AvrRps4. Similar systems have been used for functional studies of oomycete effectors delivered as fusions into Nicotiana benthamiana and Arabidopsis thaliana (Fabro et al. 2011; Rentel et al. 2008; Whisson et al. 2007). Recently, the bacterial pathogen Burkholderia glumae has been used to deliver effectors from Magnaporthe oryzae into rice cells (Sharma et al. 2013).

Thomas and associates (2009) developed the P. fluorescens effector-to-host analyzer strain (EtHAn), which has the $P$. syringae pv. syringae $61 \mathrm{hrp} / \mathrm{hrc}$ cluster (T3SS machinery) stably integrated into the chromosome, thereby making this nonpathogenic bacterium T3SS competent for effector delivery. This was shown to function for delivery of various $P$. syringae effectors into A. thaliana (Thomas et al. 2009), and Yin and Hulbert (2010) found that $P$. fluorescens EtHAn expressing AvrRpm1 or AvrRpt 2 induced $\mathrm{H}_{2} \mathrm{O}_{2}$ production in wheat, suggesting that it may be suitable for effector delivery in cereals. In this study, we report the development of an efficient system of effector delivery into wheat, based on T3SS delivery by $P$. fluorescens EtHAn, which has enabled the screening of candidate Puccinia graminis $\mathrm{f}$. sp. tritici effectors for avirulence activity.

\section{RESULTS}

\section{Xanthomonas translucens and Pseudomonas fluorescens T3SS deliver calmodulin-dependent adenylate cyclase to wheat seedling leaves.}

A calmodulin-dependent adenylate cyclase (Cya) assay has previously been used to demonstrate the T3SS-dependent translocation of effector: Cya protein fusions in several dicot pathosystems (Casper-Lindley et al. 2002; Schechter et al. 2004; Triplett et al. 2009). In each case, the calmodulin-dependent Cya protein domain was fused to a bacterial effector or Avr protein for delivery by the bacterial T3SS. The principle of this reporter system is that the Cya protein is inactive in prokaryotes but becomes active in the presence of calmodulin, which is present only in eukaryotic cells. Cya activity results in the production cAMP which can be readily quantified by an enzyme immunometric assay (Pradelles et al. 1989). Examples of Cya delivery include an AvrBs2:Cya fusion protein delivered by Xanthomonas spp. into pepper (Casper-Lindley et al. 2002), an AvrPto:Cya fusion delivered by Pseudomonas spp. into tomato and tobacco (Schechter et al. 2004), a DspA/E:Cya fusion delivered by Erwinia spp. into tobacco (Triplett et al. 2009), and RipA:Cya and RipG:Cya (and three other effector:Cya fusions) delivered by Ralstonia solanacearum into Arabidopsis (Cunnac et al. 2004).

Two bacterial strains were selected for the development of a T3SS delivery system for wheat and barley-Xanthomonas translucens DAR61454 (Gardiner et al. in press) which was originally isolated as a wheat pathogen and Pseudomonas fluorescens EtHAn (Thomas et al. 2009). Infiltration of wheat seedling leaves with $X$. translucens DAR61454 cells at an optical density at $600 \mathrm{~nm}\left(\mathrm{OD}_{600}\right)$ of 1.0 produced spreading water soaked lesions within $72 \mathrm{~h}$ (Fig. 1A) that later became necrotic (Fig. 1B). As reported by Gardiner and associates (in press), X. translucens DAR61454 proliferated in wheat leaves, increasing from approximately $10^{4}$ to $10^{9} \mathrm{CFU} /$ unit leaf area over 4 days (Fig. 1C). In contrast $P$. fluorescens EtHAn neither produced symptoms on wheat (Fig. 1A and B) nor showed any substantial proliferation (after infiltration into wheat leaves) (Fig. 1C). At low inoculation density $\left(\mathrm{OD}_{600}=0.001\right)$, a slight increase in $P$. fluorescens EtHAn cell counts (approxi- mately $1 \log$ ) was observed after 4 days but there was no further multiplication after (data not shown).

Each bacterial strain was transformed with a construct containing a promoter and T3SS signal sequence from a known $A v r$ gene fused in frame to the Cya domain in the broad hostrange plasmid vector pVSP61. The construct used in X. translucens DAR61454 contained the promoter and T3SS signal encoding sequences from the $X$. campestris AvrBs 2 gene while the $P$. fluorescens EtHAn construct used the T3SS sequence from the $P$. syringae AvrRpml gene. Substantial cAMP was detected $8 \mathrm{~h}$ after syringe infiltration of both strains of bacteria $\left(\mathrm{OD}_{600}=0.4\right)$ (Fig. 2) into wheat ('BW56') seedling leaves, whereas no cAMP accumulation was observed with mock infiltration $\left(10 \mathrm{~mm} \mathrm{MgCl}_{2}\right)$ or with infiltration of control strains containing respective empty vector constructs. After $24 \mathrm{~h}$ of infiltration, cAMP accumulation had increased several fold with the $X$. translucens DAR61454 transformant but no further increase was observed with the P. fluorescens EtHAn transformant. Presumably, the ability of $X$. translucens DAR61454 to multiply during infection enables increased amounts of the Cya fusion protein to be delivered to wheat cells, resulting in increased cAMP production. Obvious disease symptoms were present on wheat leaves infected with $X$. translucens DAR61454 transformants by $72 \mathrm{~h}$. These data indicate that both these bacterial strains can deliver protein into wheat leaf cells via a bacterial T3SS.

\section{Development and refinement of bacterial T3SS system for effector delivery to wheat and other plant species.}

To facilitate high-throughput screening of effector candidates, three vectors were engineered to accommodate GATEWAY cloning: pNR494 for use with $X$. translucens and pNR557 and pNR526 for use with $P$. fluorescens (Supplementary Fig. $\mathrm{S} 1)$. The backbone in these constructs was the broad-host-range vector pBBR 1MCS-5 (Kovach et al. 1995; Sohn et al. 2007). These vectors encode promoter and T3SS signals from the $X$. campestris AvrBs2 gene (pNR494) and P. syringae AvrRps4 gene (pNR557) and AvrRpml gene (pNR526), respectively. In juxtaposition to these $A v r$ gene sequences are GATEWAY cloning sites that flank a chloramphenicol selectable marker gene and $c c d B$ negative selectable marker gene, with a hemagglutinin (HA) tag located $3^{\prime}$ of the GATEWAY cassette. Vector pNR557 is essentially identical to the previously reported vector pEDV6 (Kemen et al. 2011; Sohn et al. 2007).The Cya reporter was introduced by GATEWAY cloning into these destination vectors (the list of constructs used and made in this study is shown in Supplementary Table S2) and tested in $X$. translucens DAR61454 and P. fluorescens EtHAn, respectively.

To determine the applicability of $X$. translucens and $P$. fluorescens bacterial delivery systems to other plant species, $X$. translucens DAR61454 containing AvrBs2 T3SS:Cya (pNR495) and P. fluorescens EtHAn with AvrRpm1 T3SS:Cya (pNR527) were infiltrated into wheat, barley, flax, brachypodium, and rice leaves, and Cya activities were measured $18 \mathrm{~h}$ postinfiltration (Fig. 3). Wheat showed substantial Cya activity with either delivery system, with the $X$. translucens DAR61454 again resulting in significantly higher cAMP accumulation. Significant levels of cAMP were also detected in barley leaf tissue, although less than that observed for wheat. In contrast, only very low levels of cAMP were detected in brachypodium, flax, and rice with both $X$. translucens and $P$. fluorescens. It should be noted, however, that both brachypodium and rice were relatively difficult to syringe infiltrate with bacterial cultures and, therefore, the poor cAMP production in these species could be due to low levels of bacterial inoculum getting infiltrated. Alternative methods, such as vacuum infiltration, may be necessary to facilitate delivery into these plants. 
cAMP was detected in wheat leaves infiltrated with $P$. fluorescens EtHAn strains containing the AvrRpm1 T3SS:Cya (pNR527) but not AvrRps4 T3SS:Cya (pNR528) fusions in these vectors (Fig. 4A), suggesting that AvrRps4 T3SS signals are not appropriate for this Cya delivery assay. Increasing the cell density of $P$. fluorescens EtHAn containing AvrRpm1
T3SS:Cya (pNR527) resulted in increased Cya activity, which was optimum at $\mathrm{OD}_{600}>1.2$ (Fig. 4B).

The bacterial T3SS system is inactive in cells grown in rich media but is induced when bacteria are either infiltrated into plants, grown in minimal medium, or grown with fructose or sucrose as the carbon source (Huynh et al. 1989; Stauber et al.
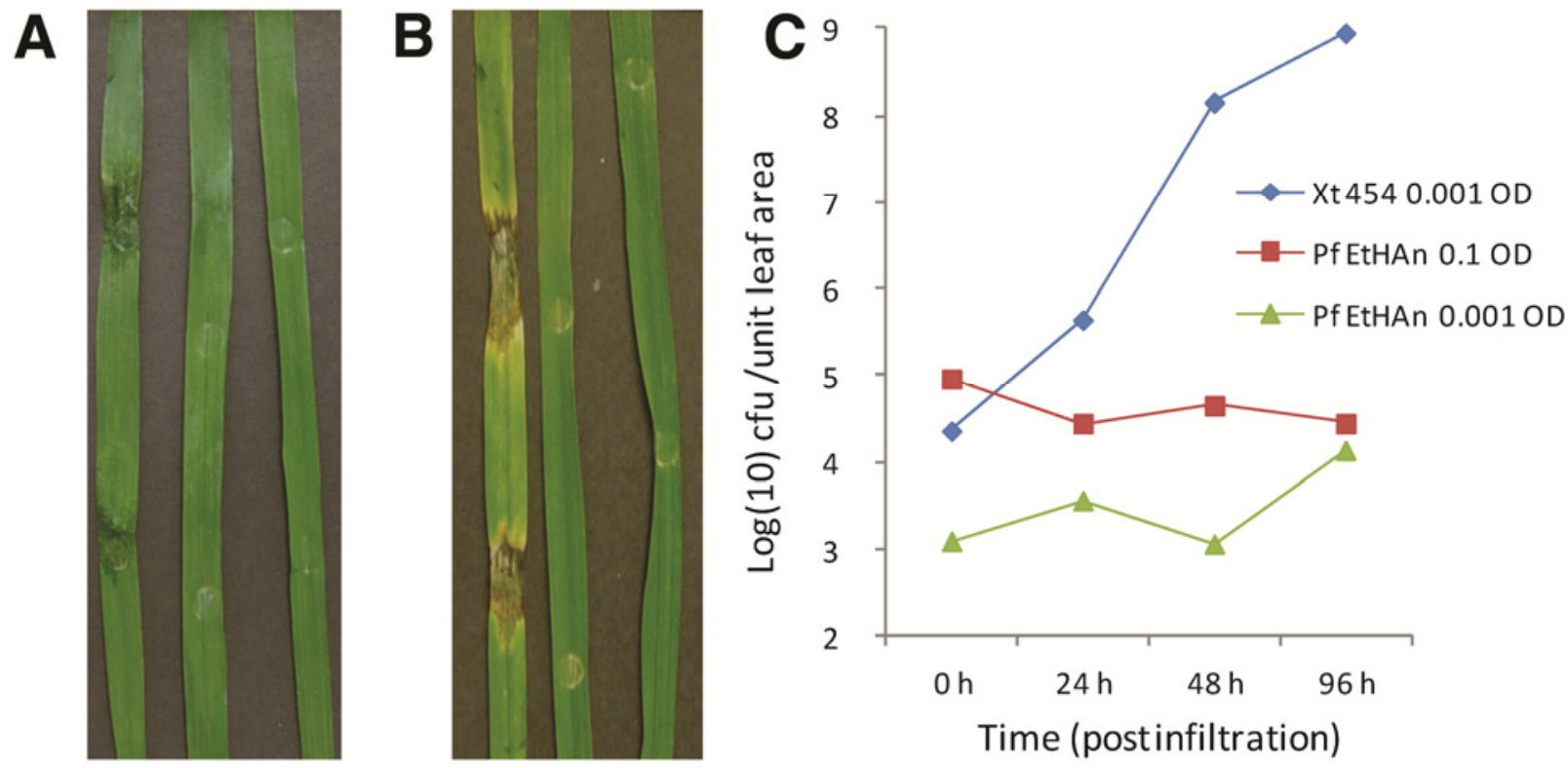

Fig. 1. Response to infiltration of Xanthomonas translucens and Pseudomonas fluorescens into 'BW56' wheat. A, Leaves from BW56 wheat 3 days postinfiltration with $X$. translucens DAR61454 (left leaf), $P$. fluorescens effector-to-host analyzer strain (EtHAn) (middle leaf), and mock (10 mM MgCl ${ }_{2}$; right leaf). X. translucens infiltration resulted in obvious water-soaking symptoms but no symptoms were observed upon infiltration with $P$. fluorescens or $10 \mathrm{mM}$ $\mathrm{MgCl}_{2}$ alone. B, Wheat (BW56) seedling leaves 7 days postinfiltration with (from left to right) X. translucens DAR61454, P. fluorescens EtHAn, and $10 \mathrm{mM}$ $\mathrm{MgCl}_{2}$. With $X$. translucens, initial water-soaking symptoms were followed by necrosis. C, Bacterial counts over time after infiltration (20 to $30 \mu 1$ per spot) of wheat (BW56) seedling leaves with rifampicin-resistant X. translucens DAR61454 (optical density at $600 \mathrm{~nm}\left[\mathrm{OD}_{600}\right]$ of $0.001 \mathrm{or} 3.9 \times 10^{5} \mathrm{CFU} / \mathrm{ml}$ ) and chloramphenicol-resistant $P$. fluorescens EtHAn at specified cell densities $\left(\mathrm{OD}_{600}\right.$ of 0.001 or $7.5 \times 10^{5} \mathrm{CFU} / \mathrm{ml}$ and $\mathrm{OD}_{600}$ of 0.1 or $\left.8 \times 10^{7} \mathrm{CFU} / \mathrm{ml}\right)$. Each time-point is average of three biological replicates with error bars representing the standard error of the mean. One unit area is approximately $0.5 \mathrm{~cm}$ of leaf blade from both sides of the infiltration spots of two leaves from a plant (this amounts to approximately $30 \mathrm{mg}$ of tissue).

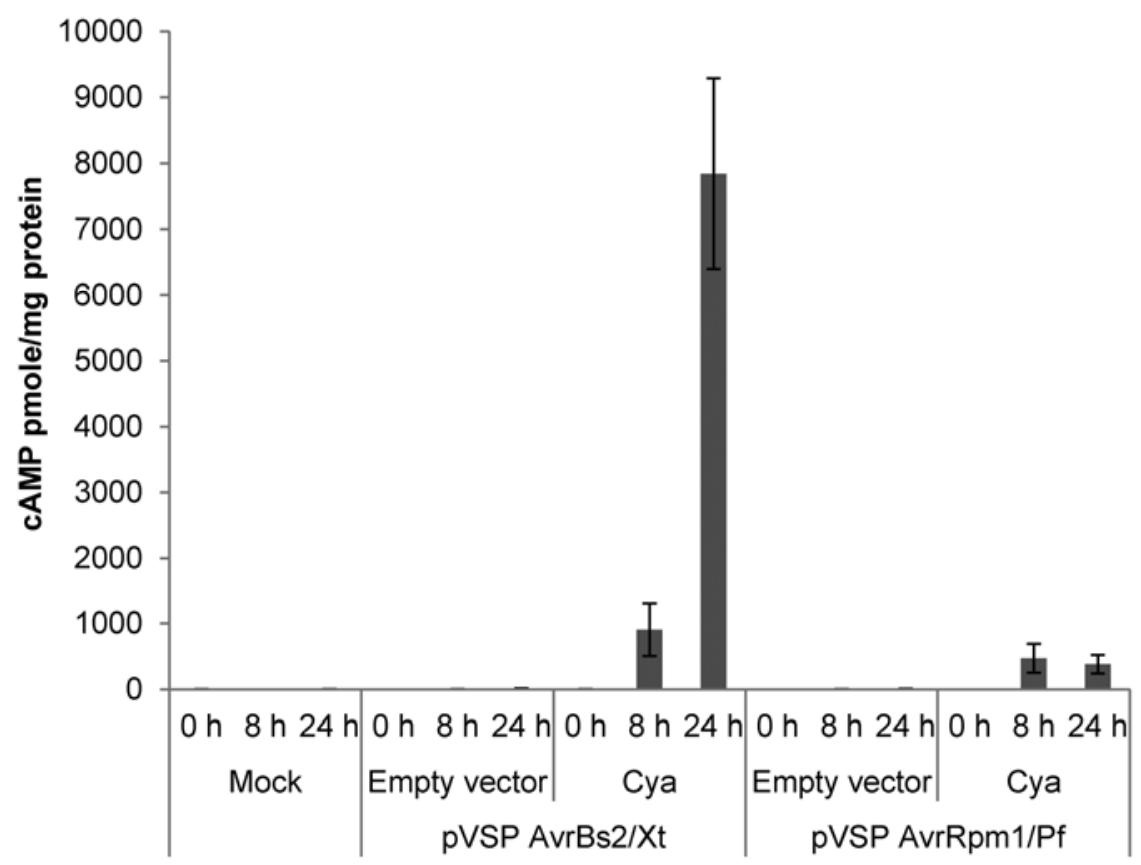

Fig. 2. Delivery of calmodulin-dependent adenylate cyclase (Cya) reporter protein to wheat leaf cells via bacterial type III secretion. Cya activity as measured by cAMP production (pmol/mg of leaf protein) in 'BW56' wheat leaves infiltrated with $\mathrm{MgCl}_{2}$ (mock), empty vector strains pVSP-AvrBs2 T3SSHA/Xanthomonas translucens DAR61454 and pVSPAvrRpm1 T3SS-HA/Pseudomonas fluorescens EtHAn (optical density at $600 \mathrm{~nm}\left[\mathrm{OD}_{600}\right]=0.4$ ), and Cya expression strains pVSP-AvrBs2 T3SS:Cya/X. translucens DAR61454 and pVSPAvrRpm1 T3SS:Cya/P. fluorescens EtHAn $\left(\mathrm{OD}_{600}=0.4\right)$, sampled 0, 8, and $24 \mathrm{~h}$ after infiltration. Values are average of three replicates and the error bars represent standard error. 
2012). To determine whether preinduction of the T3SS increased Cya reporter delivery, $P$. fluorescens EtHAn containing AvrRpm1 T3SS:Cya (pNR527) was initially grown in rich medium (Luria-Bertani [LB]) and then shifted to a minimal medium supplemented with $10 \mathrm{mM}$ fructose prior to infiltration. Although we observed an increase in Cya activity using this induced inoculum, this was not statistically significant (Fig. $4 C)$.

It has been demonstrated that AvrRpm1 is targeted to the host plasma membrane by myristoylation and palmitoylation and this localization enhances its Avr activity (Nimchuk et al. 2000). AvrRpm1 contains a single myristoylation site and palmitoylation site at the $\mathrm{N}$ terminus of the protein which are located at the second glycine $(\mathrm{G})$ residue and the third cysteine (C) residue, respectively. These $\mathrm{G} 2$ and $\mathrm{C} 3$ residues were substituted with alanine either singly or in combination and the effect on protein delivery by $P$. fluorescens EtHAn determined. In wheat, all three AvrRpm1 T3SS mutated vectors (G2A, $\mathrm{C} 3 \mathrm{~A}$, and $\mathrm{G} 2 \mathrm{AC} 3 \mathrm{~A}$ ) fused to the Cya open reading frame reduced cAMP accumulation compared with the wild-type AvrRpm1 T3SS fusion (Fig. 4D). This may be because Cya activity requires interaction with plasma-membrane-localized calmodulin.

\section{P. fluorescens T3SS-mediated delivery of a flax rust Avr protein results in an HR in tobacco expressing corresponding $\mathbf{R}$ protein.}

Although the above results indicated that $P$. fluorescens EtHAn could effectively deliver the Cya reporter protein into wheat cells, it was not known whether this system could deliver a functional rust Avr protein in a form that allows recognition by a host $R$ gene. Because no cereal rust Avr proteins have been identified, an AvrRpm1 T3SS fusion was generated with the flax rust AvrM protein which is recognized by the corresponding flax $\mathrm{M}$ resistance protein (Catanzariti et al. 2006). Because we did not observe Cya delivery in flax, we

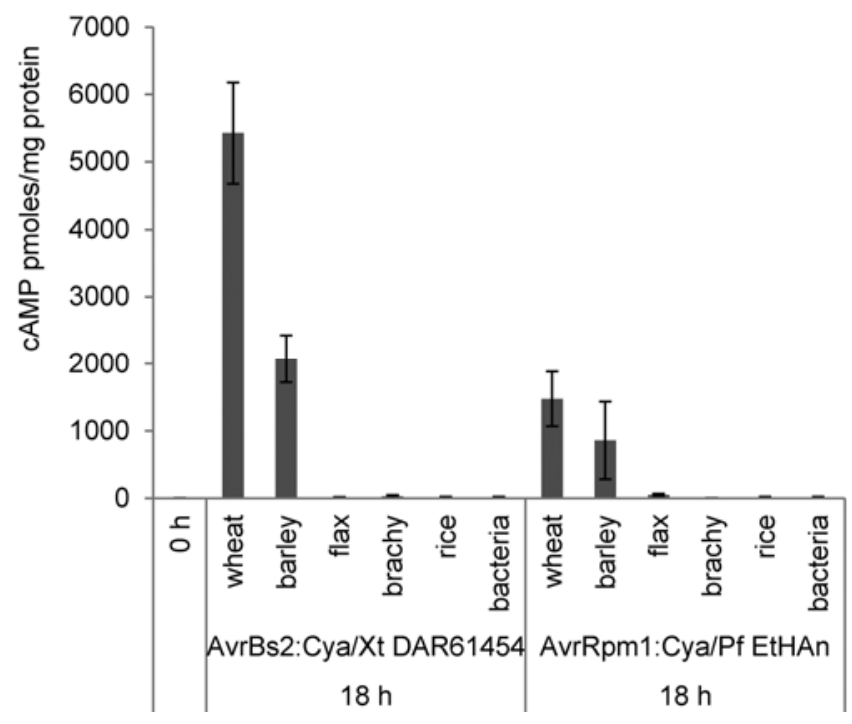

Fig. 3. Efficacy of bacterial (Xanthomonas translucens and Pseudomonas fluorescens) T3SS in calmodulin-dependent adenylate cyclase (Cya) reporter protein delivery to leaf tissues of wheat, barley, flax, brachypodium, and rice. cAMP accumulation in plant leaf tissues $18 \mathrm{~h}$ postinfiltration with $X$. translucens DAR61454 and $P$. fluorescens effector-to-host analyzer strain (EtHAn) (optical density at $600 \mathrm{~nm}$ of 0.4 in $10 \mathrm{mM}$ $\mathrm{MgCl}_{2}$ ) harboring AvrBs2 T3SS:Cya (pNR495) and AvrRpm1 T3SS:Cya (pNR527) constructs, respectively. A 0-h sample and respective bacterial inoculums $(50 \mu \mathrm{l})$ were used to detect any background Cya activity (cAMP production). Values are average of three replicates and the error bar indicates standard error. tested this construct in tobacco ( $N$. tabacum), which does support Cya delivery (Supplementary Fig. S2). P. fluorescens EtHAn containing the AvrM construct was infiltrated into transgenic tobacco expressing the $M$ gene and a strong HR was observed (Fig. 5A). No HR was observed when $P$. fluorescens EtHAn expressing the virulence form $a v r M$, which is not recognized by $\mathrm{M}$, was infiltrated in the $\mathrm{M}$ tobacco (Fig. 5A), consistent with the known specificity of the $M$ resistance protein. This response was similar to or greater in intensity than the response generated by Agrobacterium-mediated transient expression of AvrM (Fig. 5A), indicating that this system delivers the rust effector very efficiently.

In contrast to Cya reporter activity in wheat (Fig. 4D), the G2A and G2AC3A mutations in the AvrRpm1 myristoylation sites enhanced the cell death response relative to the wild-type when fused with AvrM in this assay (Fig. 5B). Normally, older leaves show reduced HR response compared with younger ones in these assays. Both mutated and unmutated versions of the AvrRpm1 T3SS:AvrM fusion construct strains showed strong HR in younger leaves (Fig. 5C) but such responses in older leaves (induced cultures) were strong only with $\mathrm{G} 2 \mathrm{~A}$ and G2AC3A mutant versions (Fig. 5D). These data indicate that targeting signals present on the AvrRpm1 T3SS peptide can have a significant impact on AvrM detection.

\section{Identification of a candidate avirulence effector in Puccinia graminis f. sp. tritici.}

We have identified approximately 336 candidate effector sequences (unpublished data) from an Australian isolate of Puccinia graminis $\mathrm{f}$. sp. tritici. Expression vectors (using the destination vector pNR526 G2AC3A) were made with 40 of these genes (one or more alleles of approximately 25 candidate effectors), mobilized into Pseudomonas fluorescens EtHAn, and were screened for their ability to induce wheat genotype-specific HR (avirulence activity). We inoculated 18 wheat varieties which collectively possess 24 different stem rust resistance genes (Supplementary Table S3). One gene (PGTAUSPE-10-1) induced a clear HR response 24 to $36 \mathrm{~h}$ postinfiltration specifically on wheat line W3534, consistent with an avirulence activity (Fig. 6). At least two variants of this candidate Avr gene were obtained by polymerase chain reaction (PCR) amplification from Puccinia graminis f. sp. tritici 21-0 RNA, only one of which induced an HR in the delivery assay (Fig. 6). Fusion of this protein to the wild-type AvrRpm1 T3SS peptide did not induce an HR (data not shown), suggesting that this candidate effector is not recognized when targeted to the plasma membrane.

\section{DISCUSSION}

In this study, T3SS signals from both AvrRpm1 and AvrBs2 fused to Cya delivered fusion proteins to wheat leaf cells from two different bacterial species. Although $X$. translucens DAR61454 delivered higher levels of Cya, resulting in increased activity, the disease symptoms produced by this bacterium make it unsuitable for detecting an HR induced by potential Avr proteins; hence, the Pseudomonas fluorescens EtHAn system is more suited to high-throughput screening of candidate effectors for recognition by host $R$ genes.

The subcellular targeting of the TTSS fusion protein appeared to be an important factor for the detection of transferred protein. It has been reported that calmodulin, an essential co-factor for Cya, is localized at the plant plasma membrane (Collinge and Trewavas 1989); hence, AvrRpm1 targeting of Cya to the plasma membrane is likely to be advantageous for enzyme activity. Consistent with this, removal of the myristoylation or palmitoylation sites from the AvrRpm1 T3SS resulted in substantially re- 
duced Cya activity in wheat cells (Fig. 4D). However, this did not affect recognition of AvrM in tobacco expressing the M resistance protein, which can normally recognize cytosolic AvrM (Rafiqi et al. 2010). Conversely, the Puccinia graminis f. sp. tritici avirulence candidate we identified only triggered an HR when delivered without AvrRpm1 plasma membrane targeting signals, further indicating that the site of effector delivery is an important factor in detection. Similarly, the Hyaloperonospora arabidopsidis effector, ATR39-1, caused an HR on an Arabidopsis accession carrying the corresponding $R$ gene, RPP39, only when delivered as an AvrRps4 fusion rather than an
AvrRpm1 fusion, resulting in an HR (Goritschnig et al. 2012), possibly because AvrRps4 is nucleocytosolic (Wirthmueller et al. 2007). These observations suggest that testing as both membrane-targeted and free cytosolic proteins may be required to detect Avr candidates using bacterial delivery systems.

We did not detect any Cya activity in infiltrated wheat when this protein was expressed with the AvrRps4 TTSS in Pseudomonas fluorescens EtHAn. Although this could be partly because of the cytosolic localization, as discussed above, PGTAUSPE-10-1 also failed to induce HR in W3534 wheat when fused to the AvrRps4 T3SS (data not shown). AvrRps4-
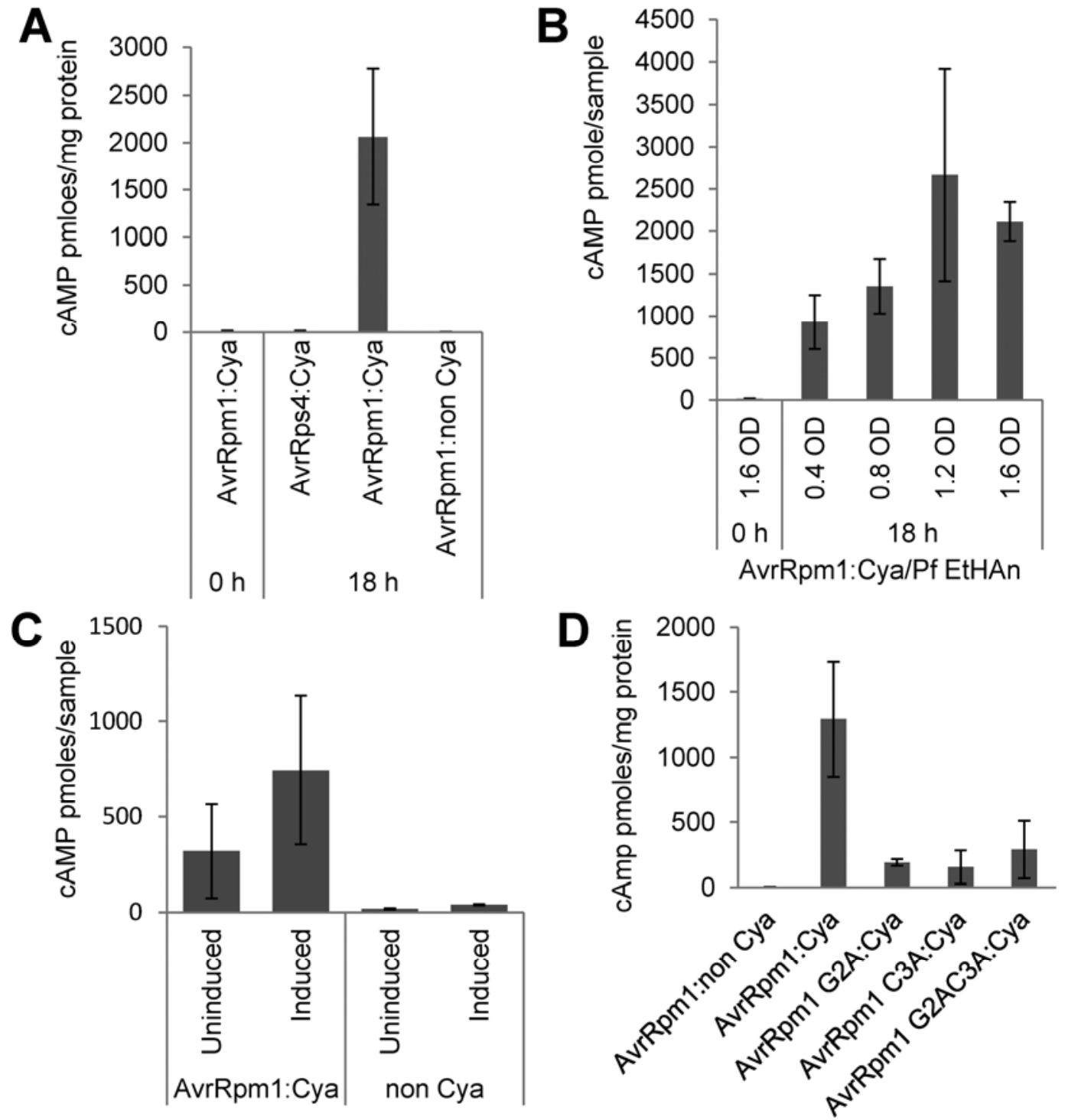

Fig. 4. Efficacy of AvrRpm1 in delivering the calmodulin-dependent adenylate cyclase (Cya) reporter protein to wheat leaf cells via Pseudomonas fluorescens effector-to-host analyzer strain (EtHAn). A, Cya activity as measured by cAMP production (pmol/mg of leaf protein) in wheat seedling samples infiltrated with $P$. fluorescens EtHAn (Luria-Bertani media grown bacteria harvested in $10 \mathrm{mM} \mathrm{MgCl} 2$ and optical density at $600 \mathrm{~nm}\left[\mathrm{OD}_{600}\right]$ adjusted to 0.4 ) harboring either AvrRps4 T3SS:Cya (pNR528), AvrRpm1 T3SS:Cya (pNR527), or AvrRpm1 T3SS:non-Cya control construct (pNR530). A sample of AvrRpm1 T3SS:Cya (pNR527) at $0 \mathrm{~h}$ postinfiltration was included to detect any background Cya activity. Values are average of three replicates and the error bar indicates standard error (SE). B, Effect of inoculum cell density on Cya-mediated cAMP accumulation (pmol/sample) in wheat leaf tissue $18 \mathrm{~h}$ after infiltration with P. fluorescens EtHAn harboring the AvrRpm1 T3SS:Cya delivery construct (pNR527). The $\mathrm{OD}_{600}$ of each culture used for infiltration is indicated, in addition to a 0 -h control showing an absence of background cAMP. Values are average of three replicates and the error bar indicates SE. C, Effect of preinduction of $P$. fluorescens T3SS (by growth on minimal medium with fructose as carbon source) on Cya-mediated cAMP production (pmol/sample) in wheat leaf tissue $16 \mathrm{~h}$ after infiltration with P. fluorescens EtHAn harboring the AvrRpm1T3SS:Cya delivery construct. An AvrRpm1 T3SS: non-Cya construct carrying P. fluorescens EtHAn was used as control. D, Removal of myristoylation and palmitoylation sites from the AvrRpm1 T3SS peptide reduces Cya delivery into wheat leaf tissue. Seedlings were infiltrated with $P$. fluorescens EtHAn containing constructs encoding the Cya reporter gene fused to either the wild-type AvrRpm1 T3SS peptide (pNR527), the AvrRpm1 T3SS peptide with the myristoylation site removed (G2A mutation, pNR590), the AvrRpm1 T3SS peptide with the palmitoylation site removed (C3A mutation, pNR592), or the same peptide with both the myristoylation and palmitoylation site removed (G2AC3A mutation, pNR594). A non-Cya-containing AvrRpm1 fusion construct (pNR542) was used as negative control. Values are average of three replicates and the error bar indicates SE. 
mediated delivery has been successful in other systems (Goritschnig et al. 2012; Sohn et al. 2007) and we did not investigate further why this fusion was not functional in our assays.

A single effector candidate from Puccinia graminis f. sp. trit$i c i$ was identified in this study that consistently induced a genotype-specific HR on a single wheat line in more than 10 experiments (Fig. 6). Wheat line W3534 carries (at the least) the stem rust resistance gene $\mathrm{Sr} 22$ (The and McIntosh 1975); thus, PGTAUSPE-10-1 is a candidate for the AvrSr22 avirulence specificity. However, when we infiltrated the same Pseudomonas fluorescens strain into unrelated wheat genotypes 'Schomburgk' and 'DK14' that are also reported to carry Sr22 (Knott 1990; Paull et al. 1994), no HR resulted (unpublished data). However, reference to the early literature indicates that a gene called $\mathrm{Sr} 22$ was independently introgressed into wheat from two different diploid wheat accessions: one, Triticum monococcum R.L.5244
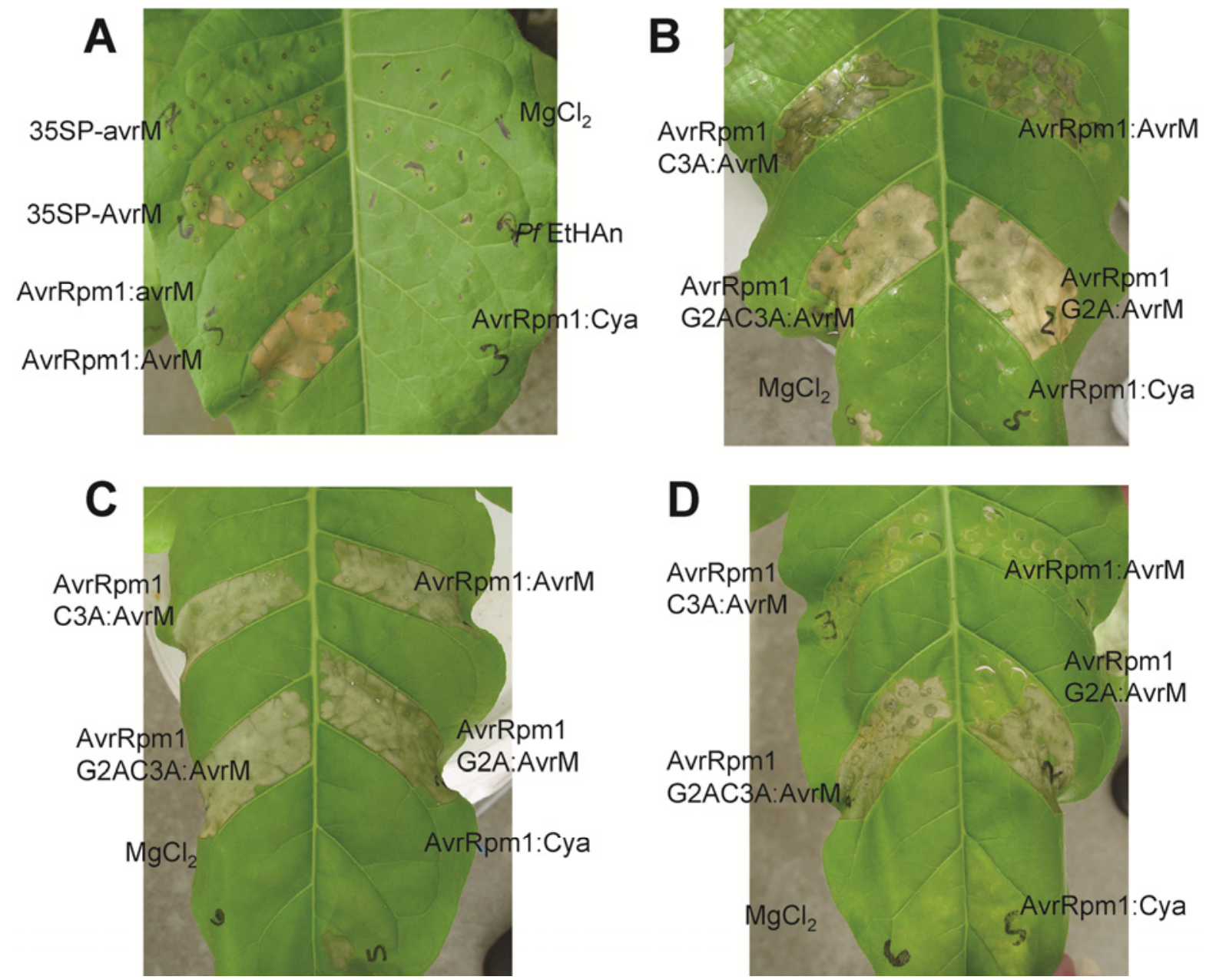

Fig. 5. Efficient delivery of AvrM to tobacco leaves by Pseudomonas fluorescens effector-to-host analyzer strain (EtHAn) via AvrRpm1 T3SS. A, Delivery of AvrM into an M transgenic tobacco (Nicotiana tabacum) leaf via either T3SS system or transient Agrobacterium expression. Leaf blade segments were infiltrated with $10 \mathrm{mM} \mathrm{MgCl}_{2}$, P. fluorescens EtHAn, P. fluorescens EtHAn containing pNR527 which encodes an AvrRpm1 T3SS: calmodulin-dependent adenylate cyclase (Cya) fusion, P. fluorescens EtHAn containing an AvrRpm1 T3SS:AvrM fusion construct pNR568, P. fluorescens EtHAn with an AvrRpm1 T3SS:avrM fusion construct pNR569 (virulent allele), an Agrobacterium strain (GV3101 pMP90) containing a 35SP-AvrM binary vector pTNotTReg-AvrM, and an Agrobacterium strain containing a 35SP-avrM (virulent allele) binary vector pTNotTReg-avrM. All culture densities were adjusted to an optical density at $600 \mathrm{~nm}$ of 1.00. Infiltrated leaves were photographed 6 days postinfiltration showing very good hypersensitive response (HR) induction with P. fluorescens T3SS-mediated AvrM delivery. B, Removal of myristoylation signals from AvrRpm1 T3SS increases efficiency of AvrM delivery. A leaf from the tobacco line expressing the $M$ resistance gene 4 days postinfiltration with EtHAn contained the following fusion constructs: AvrM fused to the wild-type AvrRpm1 T3SS sequence (pNR568), AvrRpm1 T3SS encoding a G2A substitution (pNR606), AvrRpm1 C3A T3SS (pNR608), and AvrRpm1 T3SS G2A and C3A (pNR610). EtHAn harboring AvrRpm1 T3SS:Cya (pNR527) construct and $10 \mathrm{mM} \mathrm{MgCl}_{2}$ were infiltrated to serve as controls. C, Preinduction of T3SS enhance AvrM delivery with the same constructs as in B, except that cultures used here were T3SS induced (by growth in minimal media with fructose as carbon source) and one of two younger leaves of the three leaves infiltrated is shown here (photographed 4 days after infiltration). Both mutated and unmutated versions of the AvrRpm1 T3SS:AvrM fusion construct strains (P. fluorescens EtHAn) showed strong HR with the younger two leaves. D, The third (oldest) leaf infiltrated (same time) with same constructs or cultures as in $\mathrm{C}$ and photographed 4 days after infiltration. It is worth noting that, normally, older leaves show reduced HR compared with younger ones in these assays. Even with this older leaf, HR was strong, with infiltrations of EtHAn carrying AvrRpm1 G2A T3SS:AvrM and AvrRpm1 G2AC3A T3SS:AvrM fusions. 
sis of families derived from W3534 to determine whether recognition of this effector candidate co-segregates with the $\mathrm{Sr} 22$ locus. An alternative possibility is that the HR induced by this effector in W3534 is due its recognition by a hitherto unknown $R$ gene present in this line.

The Pseudomonas fluorescens delivery system plus the candidate $A v r$ gene we report here will now be useful to optimize conditions for effector delivery to wheat and will be very useful for the large-scale screening of candidate effectors from Puccinia graminis f. sp. tritici and other pathogen species that infect wheat and barley for avirulence activity. Apart from the scientific interest in what constitutes an Avr protein, there are potential applications for this delivery system. The identification of Avr proteins through this transient assay will enable the biological discrimination or unification of co-segregating resistance genes introduced into wheat from different sources, particularly when these genes provide resistance to all known $P$. graminis $\mathrm{f}$. sp. tritici races and, therefore, the resistance specificities are not distinguished using pathogen bioassays. As described above, the Sr22 gene is potentially such an example. In addition, when pyramiding multiple resistance genes that are effective against all pathogen races by transgenesis, it is not possible to confirm that all transgenes are functional by conventional pathology assays. The activity of each gene can potentially be confirmed using the Pseudomonas fluorescens assay we have described in conjunction with the appropriate recognized effectors. Finally, delivery of candidate effectors to unimproved wheat lines or wild relatives may enable the rapid identification of hitherto unidentified $R$ genes in germplasm banks.

\section{MATERIALS AND METHODS}

Plasmid vectors used and constructed.

All constructs used or made in this study are listed in Supplementary Table S1. Cya expression vectors used in the preliminary assays were pVSP nPro+AA1-75-AvrBs2:Cya (for Xanthomonas spp.) and pVSP nPro+AA1-89-AvrRpm1:Cya (for Pseudomonas spp.). pVSP nPro+AA1-75-AvrBs2:Cya contains the AvrBs 2 promoter (178 nucleotides [nt]), the first $225 \mathrm{nt}$ of AvrBs 2 coding region from $X$. campestris pv. vesicatoria (Casper-Lindley et al. 2002), and the cya domain from cyclosin gene of Bordetella pertussis (Sory and Cornelis 1994) cloned as Cya expression cassette in the broad-host-range vector pVSP61 (Loper and Lindow 1987). pVSP nPro+AA1-89AvrRpm1:Cya contains the AvrRpm1 promoter (189 nt) and the first 267 nt of AvrRpml (Dangl et al. 1992; Rentel et al. 2008) fused to the cya domain. pEDV5 (Sohn et al. 2007), containing the AvrRps4 promoter (129 nt), a 5' coding region (411 nt), an HA tag (27 nt), and a multiple cloning site (MCS) (including ClaI), was provided by J. Jones (Sainsbury Laboratory, Norwich, U.K.).

To render these vectors amenable for GATEWAY cloning, appropriate reading frame cassettes $\left(a t t \mathrm{R} 1-c c d \mathrm{~B}-\mathrm{Cm}^{\mathrm{R}}-a t t \mathrm{R} 2\right.$ Gateway Vector Conversion System; Invitrogen, Carlsbad, CA, U.S.A.) were introduced by restriction digest and ligation. pEDV5 (pEDV-AvrRps4-MCS-HA) was digested with ClaI, end-filled, and ligated with the reading frame A cassette to produce the destination vector pNR557 or pEDV-AvrRps4-HADes1 (same as pEDV6) (Kemen et al. 2011; Sohn et al. 2007). pVSP61-AvrBs2P-AvrBs2-HA (Mudgett et al. 2000) was digested with EcoRV and the reading frame A cassette was introduced to generate the destination vector pNR558 or pVSP61-AvrBs2-HA-Des1. Because the pVSP61 vector backbone is large (approximately $11 \mathrm{kbp}$ ) and contains the kanamycin resistance marker which is also present in the pENTR/D Topo entry vectors, we replaced this with the pEDV vector backbone (approximately $4.5 \mathrm{kbp}$, gentamycin selection) for the
AvrRpm1 and AvrBs2 fusion constructs (pNR526 and pNR494, respectively). pNR494 (pEDV-AvrBs2-HA-Des2) was generated as follows. The destination vectors pNR557 and pNR558 were digested with HindIII/ApaL1 and the pNR558 fragment containing AvrBs2 P-AvrBs2 T3SS, and part of the $\mathrm{cm}^{\mathrm{R}} / c c d \mathrm{~B}$ was ligated to the pNR557 fragment containing pEDV5 backbone and part of $c c d$ B to get pNR559 or pEDV-AvrBs2-Des1. pNR558 and pNR559 were then digested with EcoR1 and the smaller fragment from pNR558 (containing part of $\mathrm{Cm}^{\mathrm{R}}, c c d \mathrm{~B}$, attR2, and HA) and the larger fragment from pNR559 (containing pEDV5 backbone, AvrBs2 T3SS, attR1, and part of $\mathrm{cm}^{\mathrm{R}}$ ) were ligated to get pNR494 or pEDV-AvrBs2-HA-Des2.

To generate pNR526 containing the AvrRpm1 GATEWAY cassette fusion in the pEDV vector backbone, the EcoR1/ HindIII fragment (AvrRps4-T3SS-HA cassette) in pEDV5 was first replaced with the EcoR1/HindIII fragment (AvrBs2 P-AvrBs2 T3SS-HA cassette) from pVSP61-AvrBs2P-AvrBs2 T3SS-HA to get pEDV-AvrBs2P-AvrBs2-HA. Then, the AvrRpm1 P-AvrRpm1 T3SS cassette was amplified from pVSP nPro+aa1-89-AvrRpm11:Cya with primers AvrRpm1_F (5'GTCTTAAGCTTAATTCGGCAAAAATCGTACGCAGG-3') and AvrRpm1_R (5'-AATGGGATCCGATATCCTCGGTTG CACCATCAGTTTTTC-3') to insert 5' HindIII and 3' EcoRV/ BamH1restriction sites. This PCR fragment was digested with HindIII/BamHI and inserted into HindIII/BamHI-digested pEDV-AvrBs2P-AvrBs2-T3SS-HA, replacing the AvrBs2 cassette to get pNR523 (pEDV-AvrRpm1P-AvrRpm1-T3SS-HA). The EcoRI/HindIII fragment from this construct was cloned into pNEB193 (New England Biolabs, Beverly, MA, U.S.A.), and the reading frame A cassette (GATEWAY) inserted into the EcoRV site, and then replaced (EcoRI-EcoRI-HindIII partially digested fragment) into pNR523 to get pNR526 (pEDVAvrRpm1-HA-Des1N).

The AvrRpm1 myristoylation sites were mutated in the destination vector pNR526 using the Quick Change II XL SiteDirected Mutagenesis kit (Agilent Technologies, Santa Clara, CA, U.S.A.) reagents according to the manufacturer's instruc-

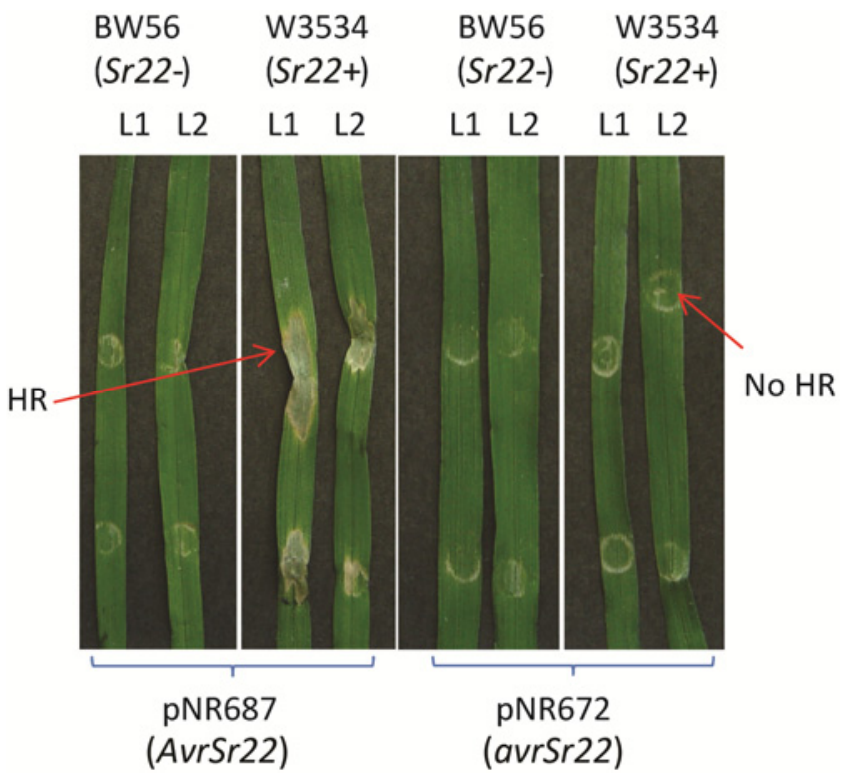

Fig. 6. Identification of a candidate avirulence effector from wheat stem rust Puccinia graminis f. sp. tritici 21-0 showing host-specific hypersensitive response (HR). First (L1) and second (L2) leaves of 'BW56' and 'W3534' wheat infiltrated with Pseudomonas fluorescens effector-to-host analyzer strain (EtHAn) containing delivery constructs that encode the AvrRpm1 G2AC3A T3SS fused to effector (PGTAUSPE10) variant 1 (pNR687) or variant 2 (pNR672). These were photographed 9 days postinfiltration. 
tion. The following PCR conditions were employed: $95^{\circ} \mathrm{C}$ for $1 \mathrm{~min}, 1$ cycle; $95^{\circ} \mathrm{C}$ for $50 \mathrm{~s}, 60^{\circ} \mathrm{C}$ for $50 \mathrm{~s}$, and $68^{\circ} \mathrm{C}$ for $7 \mathrm{~min}$, 18 cycles; and $68^{\circ} \mathrm{C}$ for $7 \mathrm{~min}, 1$ cycle. ccdB survival cells (Invitrogen) were used for transformation according to the manufacturer's protocol. Mutations were confirmed by sequencing.

All GATEWAY entry vectors for Cya, AvrM, avrM, and candidate effectors were constructed in pENTR/D-TOPO according to the manufacturer's (Invitrogen) instructions. Primers used in this study are listed in Supplementary Table 2. PCR amplifications were performed using the Phusion highfidelity DNA polymerase (Thermo Scientific, Waltham, MA, U.S.A.) according to manufacturer's instructions. Stem rust effector candidate gene sequences were amplified from cDNA prepared from RNA isolated from purified haustoria of the Australian wheat stem rust (Puccinia graminis sp. tritici, strain 21-0), with the predicted signal peptide excluded and the final stop codon included so that no C-terminal tag was introduced. Inserts were introduced into the GATEWAY destination vectors by an LR clonase reaction according to the manufacturer's instructions. Plasmids were confirmed by sequencing and analyzed using Vector NTI Advance (Life Technologies, Gaithersburg, MD, U.S.A.) or CodonCode Aligner V.4.0.4 software (CodonCode Corporation, Centerville, MA, U.S.A.).

\section{Bacterial strains and growth conditions.}

Bacterial cultures were grown on LB agar with appropriate antibiotics (rifampicin at $50 \mathrm{mg} / \mathrm{liter}$, chloramphenicol at 30 $\mathrm{mg} / \mathrm{liter}$, gentamycin at $20 \mathrm{mg} / \mathrm{liter}$, ampicillin at $50 \mathrm{mg} / \mathrm{liter}$, and kanamycin at $25 \mathrm{mg} / \mathrm{liter}$ ). Pseudomonas fluorescens EtHAn was normally grown at $30^{\circ} \mathrm{C}$ in $\mathrm{LB}$ with chloramphenicol selection or at $33^{\circ} \mathrm{C}$ for heat-shock-competent cell preparation and selection after transformation. A rifampicinresistant $X$. translucens DAR61454 (Gardiner et al. in press) was grown in $\mathrm{LB}$ or peptone-sucrose media at $33^{\circ} \mathrm{C}$. For standard inocula preparations, cells were harvested by centrifugation $(5,000 \times g, 10 \mathrm{~min})$ and resuspended in $10 \mathrm{mM} \mathrm{MgCl}$ to the required $\mathrm{OD}_{600}$. An Agrobacterium strain (GV3101 pMP90) containing a binary vector expressing the flax rust AvrM gene under the control of the $35 \mathrm{~S}$ promoter was used for transient expression, as described previously (Catanzariti et al. 2006).

For leaf inoculation, Pseudomonas and Xanthomonas strains were grown at $29^{\circ} \mathrm{C}$ for $24 \mathrm{~h}$ in LB medium with antibiotic selection; cells were harvested and resuspended in $10 \mathrm{mM}$ $\mathrm{MgCl}_{2}$ to specified cell density $\left(\mathrm{OD}_{600}\right.$ of 0.4 to 2.00$)$ and infiltrated into leaves using a needle-less syringe. For preinduction of the T3SS, P. fluorescens cultures, were instead resuspended in a minimal media (50 $\mathrm{mM}$ potassium phosphate buffer, 7.6 $\mathrm{mM}\left[\mathrm{NH}_{4}\right]_{2} \mathrm{SO}_{4}, 1.7 \mathrm{mM} \mathrm{MgCl}$, and $1.7 \mathrm{mM} \mathrm{NaCl}$; $\mathrm{pH} 5.7$ to 5.8) with antibiotic (gentamycin at $15 \mathrm{mg} /$ liter) and fructose $(10 \mathrm{mM})$ to a $\mathrm{OD}_{600}=0.8$, incubated at $20^{\circ} \mathrm{C}$ overnight $(200$ rpm), then centrifuged $\left(5,000 \times g\right.$ at $4^{\circ} \mathrm{C}$ for $\left.12 \mathrm{~min}\right)$ and resuspended in $10 \mathrm{mM} \mathrm{MgCl}$. For standard Cya assay, the inoculum density used was $\mathrm{OD}_{600}=0.4$. For tobacco infiltrations, the inoculum density used was $\mathrm{OD}_{600}=1.0$ and, for routine wheat infiltrations, it was $\mathrm{OD}_{600}=2.0$.

\section{Plasmid and expression vector mobilizations.}

Plasmid transfers to Escherichia coli were performed by standard heat-shock method of transformation. Plasmid minipreparations were done using the NucleoSpin plasmid prep kit (Macherey-Nagel, Düren, Germany) according to the manufacturer's instruction. Expression constructs were mobilized from E. coli to $X$. translucens DAR61454 (rifampicin marked) by triparental mating with pRK2013/HB101 or by electroporation. Electrocompetent cells were prepared by the previously described method (Sharma and Schimke 1996) using yeast extract nutrient broth salt-free medium, with some modifications. Cultures were grown at $33^{\circ} \mathrm{C}$ with shaking to and $\mathrm{OD}$ of 0.4 . The cells were harvested and washed twice with cold $10 \%$ glycerol $(1 / 10$ volume of the original culture) and finally resuspended in $1 / 50$ or $1 / 100$ volume of $10 \%$ glycerol. Cells were aliquoted in $40 \mu \mathrm{l}$ in Eppendorf tunes which were snap frozen and stored at $-80^{\circ} \mathrm{C}$. Plasmid DNA ( 250 to $\left.500 \mu \mathrm{g}\right)$ was used for standard bacterial electroporation, followed by the addition of $250 \mu \mathrm{l}$ of LB or super optimal broth with catabolic repressor glucose, incubation (slow shaking) at $33^{\circ} \mathrm{C}$ for 3 to $4 \mathrm{~h}$, plating on peptone-sucrose agar with required antibiotic selection (rifampicin and gentamycin), and incubation at $33^{\circ} \mathrm{C}$ for 48 to $72 \mathrm{~h}$.

Heat-shock-competent $P$. fluorescens cells were prepared by a method modified from the standard protocol described for $E$. coli (Sambrook et al. 1989). Modifications included growth at $33^{\circ} \mathrm{C}$ to an $\mathrm{OD}_{600}$ of 1.8 to 2.00 and use of $0.1 \mathrm{M} \mathrm{CaCl}_{2}$ as the frozen storage buffer, with the addition of dimethyl sulfoxide $(1 / 30$ volume of the resuspended cells, twice, in 15-min intervals). Aliquots $(100 \mu \mathrm{l})$ were transformed with $500 \mathrm{ng}$ of plasmid DNA, with a 2-min heat pulse at 42 to $43^{\circ} \mathrm{C}$, followed by 3 to $4 \mathrm{~h}$ of incubation with shaking at $33^{\circ} \mathrm{C}$ before plating on LB media with the required selection (chloramphenicol and gentamycin).

\section{Plant material and growth and infiltration conditions.}

Seedlings of wheat barley, rice, brachypodium, and flax were raised in small $(5 \mathrm{~cm})$ pots with a vermiculite/perlite (50:50, $\mathrm{vol} / \mathrm{vol}$ ) mixture and osmocote at $1 \mathrm{~g} /$ liter. Transgenic tobacco (N. tabacum) containing the flax $\mathrm{M}$ resistance gene (Catanzariti et al. 2006) initially propagated in sterile Murashige-Skoog media were transplanted into standard potting mix and inoculated after 3 weeks. All plants were grown in a glasshouse maintained at 20 to $24^{\circ} \mathrm{C}$ temperature and normal daylight and humidity conditions. Infiltration assays were done in a growth room maintained at $24^{\circ} \mathrm{C}$ with $16 \mathrm{~h}$ of light.

Wheat, barley, brachypodium, and rice seedlings at the stage of two to three fully expanded leaves were used for infiltration. In each leaf blade, infiltrations were done in two to three spots (depending on the size of the length of the leaf blade). Tobacco plants used had four to five fully expanded leaves. The youngest fully expanded leaf and two younger leaves were used. Flax plants used were 5 to 6 weeks old (with main shoot approximately $20 \mathrm{~cm}$ high). Infiltrated plants were either kept in a shaded mister (tobacco) or a closed box with water at the bottom (wheat, barley, rice, and flax) overnight and then maintained in a $24^{\circ} \mathrm{C}$ constant-temperature growth room with $16 \mathrm{~h}$ of light (all accept tobacco) or in the glasshouse maintained at 18 to $24^{\circ} \mathrm{C}$. Observation for HR was done two to four days after infiltration.

\section{cAMP assay from bacterial inoculated leaf tissue.}

Sampling of leaf blades in and around the infiltration area (approximately $1-\mathrm{cm}$ leaf segments ) was done at $0 \mathrm{~h}$ for treatment with Cya reporter strain and either 8,18 , or $24 \mathrm{~h}$ for all samples. Samplings were done in three replicates (each with two leaf segments), snap frozen in liquid nitrogen, and stored in $-80^{\circ} \mathrm{C}$ until use. The bacterial cultures used in the infiltration $(50 \mu \mathrm{l}$ each) were also stored for background cAMP measurements. cAMP extractions and protein measurements were performed as described previously (Casper-Lindley et al. 2002), with some modification. Samples were ground in 325 $\mu \mathrm{l}$ of $\mathrm{HClO}_{4}$ extract and centrifuged (10 min, maximum speed, at room temperature), and the supernatant (approximately 300 $\mu \mathrm{l})$ was neutralized with $40 \mu \mathrm{l}$ of $6 \mathrm{M} \mathrm{K}_{2} \mathrm{CO}_{3}$. Following centrifugation for $8 \mathrm{~min}$ at maximum speed, $200 \mu \mathrm{l}$ of supernatant 
was collected and $10 \mu \mathrm{l}$ used for cAMP measurement with a cAMP enzyme immunoassay kit (Cayman Chemical Company, Ann Arbor, MI, U.S.A.), according to the manufacturer's instructions.

\section{ACKNOWLEDGMENTS}

We thank the Two Blades Foundation for financial support; E. Cother (New South Wales Department of Primary Industries) for providing Xanthomonas DAR61454; J. Jones (The Sainsbury Laboratory, Norwich U.K.) for supplying the pEDV5 vector; and R. East, D. Bhat, and L. Ma for excellent technical assistance.

\section{LITERATURE CITED}

Bai, S., Liu, J., Chang, C., Zhang, L., Maekawa, T., Wang, Q., Xiao, W., Liu, Y., Chai, J., Takken, F. L., Schulze-Lefert, P., and Shen, Q. H. 2012. Structure-function analysis of barley NLR immune receptor MLA10 reveals its cell compartment specific activity in cell death and disease resistance. PLoS Pathog. 8:e1002752. Published online.

Barrett, L. G., Thrall, P. H., Dodds, P. N., van der Merwe, M., Linde, C. C., Lawrence, G. J., and Burdon, J. J. 2009. Diversity and evolution of effector loci in natural populations of the plant pathogen Melampsora lini. Mol. Biol. Evol. 26:2499-2513.

Casper-Lindley, C., Dahlbeck, D., Clark, E. T., and Staskawicz, B. J. 2002. Direct biochemical evidence for type III secretion-dependent translocation of the AvrBs2 effector protein into plant cells. Proc. Natl. Acad. Sci. U.S.A. 99:8336-8341.

Catanzariti, A. M., Dodds, P. N., Lawrence, G. J., Ayliffe, M. A., and Ellis, J. G. 2006. Haustorially expressed secreted proteins from flax rust are highly enriched for avirulence elicitors. Plant Cell 18:243256.

Catanzariti, A. M., Dodds, P. N., Ve, T., Kobe, B., Ellis, J. G., and Staskawicz, B. J. 2010. The AvrM effector from flax rust has a structured C-terminal domain and interacts directly with the $\mathrm{M}$ resistance protein. Mol. Plant-Microbe Interact. 23:49-57.

Chisholm, S. T., Coaker, G., Day, B., and Staskawicz, B. J. 2006. Hostmicrobe interactions: Shaping the evolution of the plant immune response. Cell 124:803-814.

Collinge, M., and Trewavas, A. J. 1989. The location of calmodulin in the pea plasma membrane. J. Biol. Chem. 264:8865-8872.

Cunnac, S., Occhialini, A., Barberis, P., Boucher, C., and Genin, S. 2004. Inventory and functional analysis of the large Hrp regulon in Ralstonia solanacearum: Identification of novel effector proteins translocated to plant host cells through the type III secretion system. Mol. Microbiol. 53:115-128

Dangl, J. L., Ritter, C., Gibbon, M. J., Mur, L. A., Wood, J. R., Goss, S., Mansfield, J., Taylor, J. D., and Vivian, A. 1992. Functional homologs of the Arabidopsis RPM1 disease resistance gene in bean and pea. Plant Cell 4:1359-1369.

Dodds, P. N., Lawrence, G. J., Catanzariti, A. M., Ayliffe, M. A., and Ellis, J. G. 2004. The Melampsora lini AvrL567 avirulence genes are expressed in haustoria and their products are recognized inside plant cells. Plant Cell 16:755-768.

Dodds, P. N., Lawrence, G. J., Catanzariti, A. M., Teh, T., Wang, C. I., Ayliffe, M. A., Kobe, B., and Ellis, J. G. 2006. Direct protein interaction underlies gene-for-gene specificity and coevolution of the flax resistance genes and flax rust avirulence genes. Proc. Natl. Acad. Sci. U.S.A. 103:8888-8893.

Duplessis, S., Cuomo, C. A., Lin, Y. C., Aerts, A., Tisserant, E., VeneaultFourrey, C., Joly, D. L., Hacquard, S., Amselem, J., Cantarel, B. L., Chiu, R., Coutinho, P. M., Feau, N., Field, M., Frey, P., Gelhaye, E., Goldberg, J., Grabherr, M. G., Kodira, C. D., Kohler, A., Kues, U., Lindquist, E. A., Lucas, S. M., Mago, R., Mauceli, E., Morin, E., Murat, C., Pangilinan, J. L., Park, R., Pearson, M., Quesneville, H., Rouhier, N., Sakthikumar, S., Salamov, A. A., Schmutz, J., Selles, B., Shapiro, H., Tanguay, P., Tuskan, G. A., Henrissat, B., Van de Peer, Y., Rouze, P., Ellis, J. G., Dodds, P. N., Schein, J. E., Zhong, S., Hamelin, R. C., Grigoriev, I. V., Szabo, L. J., and Martin, F. 2011. Obligate biotrophy features unraveled by the genomic analysis of rust fungi. Proc. Natl. Acad. Sci. U.S.A. 108:9166-9171.

Fabro, G., Steinbrenner, J., Coates, M., Ishaque, N., Baxter, L., Studholme, D. J., Korner, E., Allen, R. L., Piquerez, S. J., Rougon-Cardoso, A., Greenshields, D., Lei, R., Badel, J. L., Caillaud, M. C., Sohn, K. H., Van den Ackerveken, G., Parker, J. E., Beynon, J., and Jones, J. D. 2011. Multiple candidate effectors from the oomycete pathogen Hyaloperonospora arabidopsidis suppress host plant immunity. PLoS Pathog. 7:e1002348. Published online.
Flor, H. H. 1971. Current status of the gene-for-gene concept. Annu. Rev. Phytopathol. 9:275-296.

Gardiner, D. M., Upadhyaya, N. M., Stiller, J., Ellis, J., Dodds, P., Kazan, K., and Manners, J. M. Xanthomonas translucens pathogenic on wheat and barley: A new comparative and functional pathogenomics resource. PLoS One. In press.

Gerechter-Amitai, Z. K., Wahl, I., Vardi, A., and Zohary, D. 1971. Transfer of stem rust seedling resistance from wild diploid einkorn to tetraploid durum wheat by means of a triploid hybrid bridge. Euphytica 20:281-285.

Goritschnig, S., Krasileva, K. V., Dahlbeck, D., and Staskawicz, B. J. 2012. Computational prediction and molecular characterization of an oomycete effector and the cognate Arabidopsis resistance gene. PLoS Genet. 8:e1002502. Published online.

Huynh, T. V., Dahlbeck, D., and Staskawicz, B. J. 1989. Bacterial blight of soybean: Regulation of a pathogen gene determining host cultivar specificity. Science 245:1374-1377.

Jia, Y., McAdams, S. A., Bryan, G. T., Hershey, H. P., and Valent, B. 2000 Direct interaction of resistance gene and avirulence gene products confers rice blast resistance. EMBO (Eur. Mol. Biol. Organ.) J. 19:40044014

Kanzaki, H., Yoshida, K., Saitoh, H., Fujisaki, K., Hirabuchi, A., Alaux, L., Fournier, E., Tharreau, D., and Terauchi, R. 2012. Arms race co-evolution of Magnaporthe oryzae AVR-Pik and rice Pik genes driven by their physical interactions. Plant J. 72:894-907.

Kemen, E., Kemen, A. C., Rafiqi, M., Hempel, U., Mendgen, K., Hahn, M., and Voegele, R. T. 2005. Identification of a protein from rust fungi transferred from haustoria into infected plant cells. Mol. Plant-Microbe Interact. 18:1130-1139.

Kemen, E., Gardiner, A., Schultz-Larsen, T., Kemen, A. C., Balmuth, A. L., Robert-Seilaniantz, A., Bailey, K., Holub, E., Studholme, D. J., Maclean, D., and Jones, J. D. 2011. Gene gain and loss during evolution of obligate parasitism in the white rust pathogen of Arabidopsis thaliana. PLoS Biol. 9:e1001094. Published online.

Kerber, E. R., and Dyck, P. L. 1973. Inheritance of stem rust resistance transferred from diploid wheat (Triticum monococum) to tetraploid and hexaploid wheat and chromosome location of the gene involved. Can. J. Genet. Cytol. 15:397-409.

Knott, D. R. 1990. Near-isogenic lines of wheat carrying genes for stem rust resistance. Crop Sci. 30:901-905.

Kovach, M. E., Elzer, P. H., Hill, D. S., Robertson, G. T., Farris, M. A., Roop, R. M., 2nd, and Peterson, K. M. 1995. Four new derivatives of the broad-host-range cloning vector pBBR1MCS, carrying different antibiotic-resistance cassettes. Gene 166:175-176.

Lawrence, G. J., Dodds, P. N., and Ellis, J. G. 2007. Rust of flax and linseed caused by Melampsora lini. Mol. Plant Pathol. 8:349-364.

Leister, R. T., Ausubel, F. M., and Katagiri, F. 1996. Molecular recognition of pathogen attack occurs inside of plant cells in plant disease resistance specified by the Arabidopsis genes RPS2 and RPM1. Proc. Natl. Acad. Sci. U.S.A. 93:15497-15502.

Leonard, K. J., and Szabo, L. J. 2005. Stem rust of small grains and grasses caused by Puccinia graminis. Mol. Plant. Pathol. 6:99-111.

Loper, J. E., and Lindow, S. E. 1987. Lack of evidence for in situ fluorescent pigment production by Pseudomonas syringe pv. syringae on bean leaf surfaces. Phytopathology 77:1449-1454.

Mudgett, M. B., Chesnokova, O., Dahlbeck, D., Clark, E. T., Rossier, O., Bonas, U., and Staskawicz, B. J. 2000. Molecular signals required for type III secretion and translocation of the Xanthomonas campestris AvrBs2 protein to pepper plants. Proc. Natl. Acad. Sci. U.S.A. 97:13324-13329.

Nimchuk, Z., Marois, E., Kjemtrup, S., Leister, R. T., Katagiri, F., and Dangl, J. L. 2000. Eukaryotic fatty acylation drives plasma membrane targeting and enhances function of several type III effector proteins from Pseudomonas syringae. Cell 101:353-363.

Okuyama, Y., Kanzaki, H., Abe, A., Yoshida, K., Tamiru, M., Saitoh, H., Fujibe, T., Matsumura, H., Shenton, M., Galam, D. C., Undan, J., Ito, A., Sone, T., and Terauchi, R. 2011. A multifaceted genomics approach allows the isolation of the rice Pia-blast resistance gene consisting of two adjacent NBS-LRR protein genes. Plant J. 66:467-479.

Park, R. F. 2007. Stem rust of heta in Australia. Aust. J. Agric. Res. 58:558-566.

Paull, J. G., Pallotta, M. A., Langridge, P., and The, T. T. 1994. RFLP markers associated with $\mathrm{Sr} 22$ and recombination between chromosome 7A od bread wheat and the diploid species Triticum boeoticum. Theor. Appl. Genet. 89:1039-1045.

Periyannan, S. K., Bansal, U. K., Bariana, H. S., Pumphrey, M., and Lagudah, E. S. 2011. A robust molecular marker for the detection of shortened introgressed segment carrying the stem rust resistance gene Sr22 in common wheat. Theor. Appl. Genet. 122:1-7.

Pradelles, P., Grassi, J., Chabardes, D., and Guiso, N. 1989. Enzyme 
immunoassays of adenosine cyclic $3^{\prime}, 5^{\prime}$-monophosphate and guanosine cyclic $3^{\prime}, 5^{\prime}$-monophosphate using acetylcholinesterase. Anal Chem. 61:447-453.

Rafiqi, M., Gan, P. H., Ravensdale, M., Lawrence, G. J., Ellis, J. G., Jones, D. A., Hardham, A. R., and Dodds, P. N. 2010. Internalization of flax rust avirulence proteins into flax and tobacco cells can occur in the absence of the pathogen. Plant Cell 22:2017-2032.

Rafiqi, M., Ellis, J. G., Ludowici, V. A., Hardham, A. R., and Dodds, P. N. 2012. Challenges and progress towards understanding the role of effectors in plant-fungal interactions. Curr. Opin. Plant. Biol. 15:477482

Rentel, M. C., Leonelli, L., Dahlbeck, D., Zhao, B., and Staskawicz, B. J. 2008. Recognition of the Hyaloperonospora parasitica effector ATR13 triggers resistance against oomycete, bacterial, and viral pathogens. Proc. Natl. Acad. Sci. U.S.A. 105:1091-1096.

Sambrook, J., Fritsch, E. F., and Maniatis, T. 1989. Molecular Cloning: A Laboratory Manual, Second Edition. Cold Spring Harbor Laboratory Press, Cold Spring Harbor, NY, U.S.A.

Schechter, L. M., Roberts, K. A., Jamir, Y., Alfano, J. R., and Collmer, A. 2004. Pseudomonas syringae type III secretion system targeting signals and novel effectors studied with a Cya translocation reporter. J. Bacteriol. 186:543-555.

Sharma, R. C., and Schimke, R. T. 1996. Preparation of electrocompetent E. coli using salt-free growth medium. Biotechniques 20:42-44.

Sharma, S., Sharma, S., Hirabuchi, A., Yoshida, K., Fujisaki, K., Ito, A., Uemura, A., Terauchi, R., Kamoun, S., Sohn, K. H., Jones, J. D., and Saitoh, H. 2013. Deployment of the Burkholderia glumae type III secretion system as an efficient tool for translocating pathogen effectors to monocot cells. Plant J. 74:701-712

Sohn, K. H., Lei, R., Nemri, A., and Jones, J. D. G. 2007. The downy mildew effector proteins ATR1 and ATR13 promote disease susceptibility in Arabidopsis thaliana. Plant Cell 19:4077-4090.

Sory, M. P., and Cornelis, G. R. 1994. Translocation of a hybrid YopE-adenylate cyclase from Yersinia enterocolitica into HeLa cells. Mol. Microbiol. 14:583-594.

Stauber, J. L., Loginicheva, E., and Schechter, L. M. 2012. Carbon source and cell density-dependent regulation of type III secretion system gene expression in Pseudomonas syringae pathovar tomato DC3000. Res. Microbiol. 163:531-539.

Stokstad, E. 2007. Plant pathology. Deadly wheat fungus threatens world's breadbaskets. Science 315:1786-1787.

The, T. T. 1973. Chromosome location of genes conditioning stem rust resistance transferred from diploid to hexaploid wheat. Nat. New Biol. 241:256.

The, T. T., and McIntosh, R. A. 1975. Cytological studies in wheat VIII. Telocentric mapping and linkage studies involving Sr22 and other genes in chromosome 7AL. Aust. J. Biol. Sci. 28:531-538.

Thomas, W. J., Thireault, C. A., Kimbrel, J. A., and Chang, J. H. 2009. Recombineering and stable integration of the Pseudomonas syringae pv. syringae $61 \mathrm{hrp} / \mathrm{hrc}$ cluster into the genome of the soil bacterium Pseudomonas fluorescens Pf0-1. Plant J. 60:919-928.

Triplett, L. R., Melotto, M., and Sundin, G. W. 2009. Functional analysis of the $\mathrm{N}$ terminus of the Erwinia amylovora secreted effector DspA/E reveals features required for secretion, translocation, and binding to the chaperone DspB/F. Mol. Plant-Microbe Interact. 22:1282-1292.

Voegele, R. T., and Mendgen, K. 2003. Rust haustoria: Nutrient uptake and beyond. New Phytol. 159:93-100.

Whisson, S. C., Boevink, P. C., Moleleki, L., Avrova, A. O., Morales, J. G., Gilroy, E. M., Armstrong, M. R., Grouffaud, S., van West, P., Chapman, S., Hein, I., Toth, I. K., Pritchard, L., and Birch, P. R. 2007. A translocation signal for delivery of oomycete effector proteins into host plant cells. Nature 450:115-118.

Wirthmueller, L., Zhang, Y., Jones, J. D., and Parker, J. E. 2007. Nuclear accumulation of the Arabidopsis immune receptor RPS4 is necessary for triggering EDS1-dependent defense. Curr. Biol. 17:2023-2029.

Yin, C., and Hulbert, S. H. 2011. Prospects of functional analysis of effectors from cereal rust fungi. Euphytica 179:57-67.

Yoshida, K., Saitoh, H., Fujisawa, S., Kanzaki, H., Matsumura, H., Yoshida, K., Tosa, Y., Chuma, I., Takano, Y., Win, J., Kamoun, S., and Terauchi, R. 2009. Association genetics reveals three novel avirulence genes from the rice blast fungal pathogen Magnaporthe oryzae. Plant Cell 21:1573-1591. 